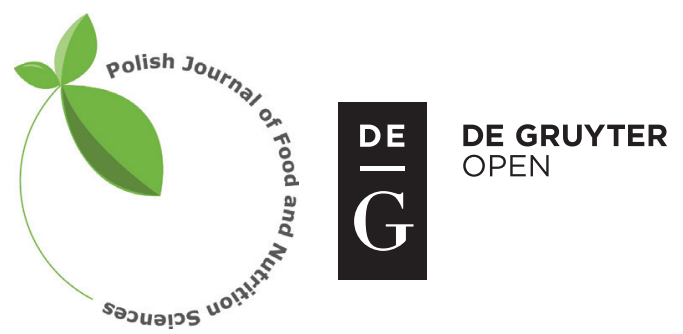

Pol. J. Food Nutr. Sci., 2018, Vol. 68, No. 4, pp. 309-317

DOI: $10.2478 /$ pjfns-2018-0004 http://journal.pan.olsztyn.pl

Original research article

Section: Food Quality and Functionality

\title{
Physical, Textural and Sensory Properties of Cookies Incorporated with Grape Skin and Seed Preparations
}

\author{
Veronika Kuchtová*, Zlatica Kohajdová, Jolana Karovičová, Michaela Lauková
}

\author{
Department of Food Technology, Institute of Food Science and Nutrition, \\ Faculty of Chemical and Food Technology, Slovak University of Technology, Radlinského 9, Bratislava, Slovakia
}

Key words: grape by-products, total dietary fibre, Mixolab, physical properties, sensory evaluation

This study is oriented to the effect of the incorporation of grape skins and grape seeds $(0,5,10$, and $15 \%$ to weight of flour) obtained from a red grape on the rheological properties of wheat dough, and on qualitative parameters and sensory properties of the prepared cookies.

With regarding to dough rheological parameters, addition of grape skins concluded in increased water absorption and reduced dough stability. The opposite effect to these parameters was observed after inclusion of grape seeds. Moreover, it was found that the addition of both types of grape skin and seed preparations resulted in reduced volume, thickness and decreased hardness of cookies. Also, it was recorded, that the addition $10 \%$ of grape seeds and 15\% of grape skins significantly decreased fracturability of cookies. The results of sensory analysis showed that the cookies incorporated with grape skins and grape seeds up to a level of 5\% resulted in products with good overall acceptability accounting for $87.44 \%$ and $91.44 \%$, respectively.

\section{INTRODUCTION}

Today, the production of high quality foods is considered a global research direction. One of the main trends in this direction is the mixing process of wheat flour used in the baking industry with flours derived from other cereals or non-grain plants, vegetables, fruits and oily seeds used to form composite flours. The purpose of using composite flours in the bakery industry is to find an adequate level of addition of these flours for processing properties. These composite flours are applied to cereal products to increase their nutritional value [Mironeasa et al., 2012].

Nowadays, there is a growing interest in the exploitation of the grape pomace, which is available at relatively low cost and provides an opportunity for the development of value-added bakery products as inexpensive non-caloric bulking agent for partial replacement of wheat flour, fat or sugar. Grape pomace, which is derived from the skins and seeds, is the by-product from grape juice and wine making [Kohajdova et al., 2012; Acun \& Gül, 2014; Karnopp et al., 2015].

However, incorporation of grape seed flour and grape pomace flour requires the modification of recipes and processing conditions to preserve the quality of the prepared bakery products [Garcia-Lomillo \& Gonzales-SanJose, 2017].

Recently several scientific studies have been oriented to the application of grape by-products into baked products such as bread [Hoye \& Ross, 2011; Walker et al., 2014], bis-

\footnotetext{
* Corresponding Author:

E-mail: veronika.kuchtova@stuba.sk (V. Kuchtova)
}

cuits [Mildner-Szkudlarz et al., 2013; Aksoylu et al., 2015], muffins [Walker et al., 2014], cookies [Davidov-Pardo et al., 2012; Acun \& Gül, 2014; Maner et al., 2017], and brownies [Walker et al., 2014], and to the determination of qualitative and sensory properties of these products.

Cookies are widely accepted and consumed in nearly all parts of the world due to being ready to eat, affordable, having good nutritional qualities, a wide range of tastes and a long shelf life [Turksoy \& Özkaya, 2011]. They are snacks which can be easily enriched with by-products from the wine-making industry that are rich in bioactive compounds.

This study provides a complete overview of the impact of the incorporation of grape preparations on the rheological properties of wheat dough, and on the quality parameters and sensory properties of the prepared cookies. Moreover, findings to be achieved in this study can also contribute to the development of new types of cookies, which should provide nutritional benefits for consumers.

\section{MATERIALS AND METHODS}

\section{Materials}

The grapes (Vitis vinifera L.) of red variety Frankova modra were acquired from the small Carpathian wine region, southwest Slovakia. The grapes were harvested at the optimum of maturity in October of 2015 year. Frankova modra (Lemberger) is an old variety of grapevine.

The following ingredients were used for cookies formulation: fine wheat flour T650 Extra (Billa, s.r.o., Bratislava, Slovakia), sugar (Považský cukor, a.s., Trenčianska Teplá, Slova- 
kia), shortening (Palma a. s., Bratislava, Slovakia), sodium chloride (Tesco Stores SR, a.s., Bratislava, Slovakia), and sodium bicarbonate (Dr. Oetker s. r. o., Bratislava, Slovakia).

\section{Obtaining the grape preparations}

The grapes were washed with tap water, then impurities and wounded fruits were removed. Next, the grapes were used for juice extraction by a juicer (Philips HR 1861, Philips, Eindhoven, Netherlands). Grape skins and grape seeds were manually separated from the pulp.

Subsequently, grape skins and grape seeds were dried at ambient temperature for 6 days and stored in plastic bags until use. Directly before analysis, skins and seeds were ground using a grinder mill (Model 0010, Eta, Hlinsko, Czech Republic) and sieved to obtain particles $400-750 \mu \mathrm{m}$ in diameter.

\section{Preparation of cookies}

Cookies were prepared according to the modified method of Kohajdová et al. [2014]. The formula of cookies was as follows: $150 \mathrm{~g}$ fine wheat flour, $42.4 \mathrm{~g}$ sugar, $39.75 \mathrm{~g}$ shortening, $1.33 \mathrm{~g}$ sodium chloride, $1.65 \mathrm{~g}$ sodium bicarbonate, and $18 \mathrm{~mL}$ water. Fine wheat flour was replaced with preparations of grape skin or seed to a level of 5,10 and 15\% in the cookie recipe. The ingredients were mixed into consistent dough. The dough was kneaded and sheeted to a uniform thickness of $2 \mathrm{~mm}$ and cut into 40-mm diameter circular shapes. Baking was carried out at $180^{\circ} \mathrm{C}$ in an electrical oven (Model 524, Mora, Czech Republic) for $8 \mathrm{~min}$. After baking, the cookies were cooled at ambient temperature, packed in polypropylene bags and sealed until further analysis.

\section{Chemical analyses}

The moisture, ash, protein, and fat contents of fine wheat flour and grape preparations were determined using the AACC methods [2000]. The content of total dietary fiber (TDF) was determined according to the gravimetric enzymatic method [AACC 1995, method 32-05; AOAC 1995, method 985.29]. The $\mathrm{pH}$ was determined using a digital $\mathrm{pH}$ meter (inoLab pH Level 2, WTW, GmbH \& Co. KG, Weilheim, Germany). The amount of pectin was determined by a gravimetric precipitation method using calcium pectate [Kohajdová et al., 2014]. The total content of carbohydrates was calculated by difference: 100 - [(moisture + ash + protein + fat + dietary fiber)]. Data were expressed as $\mathrm{g} / 100 \mathrm{~g}$ in wet weight [deMenezes et al., 2016]. The total energy was calculated using the conversion factors reported by Sousa et al. [2014] at $4 \mathrm{kcal} / \mathrm{g}$ for carbohydrates, $4 \mathrm{kcal} / \mathrm{g}$ for proteins, and $9 \mathrm{kcal} / \mathrm{g}$ for lipids.

\section{Determination of rheological properties}

The analysis of the rheological properties of dough was performed using a Mixolab 2 apparatus (Chopin Technologies, Villeneuve-la-Garenne, France) using a standard Chopin + protocol, consisting of a heating and cooling cycle at a constant speed of $80 \mathrm{rpm}$ to achieve the target value $(\mathrm{C} 1)$ of torque at $1.1 \pm 0.05 \mathrm{Nm}$. For each new analysis, the mass of flour added to the mixer was calculated automatically, taking into account the basic moisture (14\% basis, dry material) and levels of additives in the flour so that the mass of the dough was $75 \mathrm{~g}$. C It was a closed system, which injects the required amount of water according to the calculated predicted moisture of mixtures (flour, flour and grape preparations) hydration, the mixer temperature was $30^{\circ} \mathrm{C}$. The total analysis time was $45 \mathrm{~min}$, looking at the following parameters [Pastukhov \& Dogan, 2014]:

- dough stability (ST, min), and water absorption \% (WA);

- protein weakening $(\mathrm{C} 2, \mathrm{Nm}$ and difference of the points C1-C2, Nm);

- starch gelatinization $(\mathrm{C} 3, \mathrm{Nm}$ and difference of the points C3-C2, Nm);

- stability of the starch gel formed and amylase activity $(\mathrm{C} 4, \mathrm{Nm})$;

- retrogradation $(\mathrm{C} 5, \mathrm{Nm}$ and the difference of the points C5-C4, Nm).

\section{Determination of physical parameters of cookies}

The color of the cookies was measured with a UV-Vis Cary 300 Spectrophotometer (Agilent Technologies, Santa Clara, CA, USA). The parameters $\mathrm{L}^{*}, \mathrm{a}^{*}$ and $\mathrm{b}^{*}$ were determined, with illuminant D65 as the standard, and observer of $10^{\circ}$. The color results of cookies were expressed as the coordinates of the CIE Lab system. $\mathrm{L}^{*}$ is the luminance or lightness component that goes from 0 (black) to 100 (white), whereas parameter $\mathrm{a}^{*}$ goes from green to red, and parameter $\mathrm{b}^{*}$ from blue to yellow. Chroma $\left(\mathrm{C}^{*}\right)$ and hue angle ${ }^{\circ}$ were calculated according to Levent \& Bilgiçli [2013]. The total color difference $\Delta \mathrm{E}$ was calculated from the formula: $\Delta \mathrm{E}=\left(\Delta \mathrm{L}^{2}+\Delta \mathrm{a}^{2}\right.$ $\left.+\Delta \mathrm{b}^{2}\right)^{1 / 2}$ [Zielińska et al., 2005].

The hardness of cookies was measured with a TA.XT Plus Texture Analyzer (Stable Micro Systems, Godalming, United Kingdom) equipped with a 3-Point Bending Rig (HDP/3PB) according to the method described by Jambrec et al. [2013]. Hardness (peak force) was the maximum resistance of each cookie against a rounded-edge blade and occurred when the sample began to break. Fracturability was defined as the distance to peak force, and cookies with greater distance values were more compressible and less fracturable [Levent \& Bilgiçli, 2013].

The volume of cookies and volume index were determined according to the method described by Kohajdová et al. [2014]. The width (W) and thickness (T) of cookies were measured with a digital caliper. The spread ratio was calculated from the formula: spread ratio $=\mathrm{W} / \mathrm{T}$ [Kohajdová et al., 2014]. Water activity (aw) was measured using a portable water activity meter (Pawkit, Decagon Devices Inc., Pullman, WA, USA). The weights before baking and after baking were measured for three cookies. The bake loss was calculated from the formula: (weight before baking - weight after baking and cooling)/weight before baking $\times 100$ ). Bake loss was defined as the amount of water and organic material lost during baking [Alvarez-Jubete et al., 2010].

\section{Sensory evaluation of cookies}

The sensory analysis of cookies was carried out by 9 panelists following the method described by Popov-Rajlič et al. [2013]. Sensory properties such as appearance, texture, mouth sensation, aroma, color, hardness, and taste were evaluated using a score list with 5 points (1 to 5). Each point was 
precisely defined with differences between scores, The overall acceptability of cookies was evaluated using 100-mm unstructured graphic line segments describing the extreme points (minimum or maximum intensity from 0 to $100 \%$ ) [Kohajdová et al., 2014].

\section{Statistical analysis}

All statistical analyses were carried out in triplicate and average values were calculated. The results were expressed as mean \pm standard deviation. Duncan's test, at the level of $p=0.05$, was applied to the data to establish the significance of the differences between control sample and samples incorporated with grape skin and seed preparations. Statgraphic Plus, Version 3.1 (Statistical Graphic Corporation, Princeton, NY, USA) was used as the statistical analysis software.

\section{RESULTS AND DISCUSSION}

\section{Chemical composition of grape seed and skin preparations and wheat flour}

The chemical composition of grape skins and grape seeds is known to vary depending on the grape cultivar, climatic conditions during growth, processing conditions, and the proportions of the pomace [Deng et al., 2011; Yu \& Ahmedna, 2013]. The chemical composition of the raw materials used in the study is shown in Table 1. Moisture content of the fiber preparations was below 9\%, which is the upper limit for their handling and conservation [Larrauri, 1999]. It was found that grape skins had a higher ash content $(6.78 \mathrm{~g} / 100 \mathrm{~g})$ than grape seeds $(1.59 \mathrm{~g} / 100 \mathrm{~g})$. Previously, it was shown that most of the minerals were contained in the skins [Tseng \& Zhao, 2012]. Previously, it was found that protein content of grape pomace may range between $6 \mathrm{~g} / 100 \mathrm{~g}$ and $15 \mathrm{~g} / 100 \mathrm{~g}$ depending on grape variety and harvesting conditions [Garcia-Lomillo \& Gonzales-SanJose, 2017]. Protein content of grape seeds analyzed in this study was similar $(9.67 \mathrm{~g} / 100 \mathrm{~g})$ and consisted with the level described earlier for grape seeds flour by Mironeasa et al. [2012].

In the literature, there are many by-products that are valuable sources of TDF, with contents varying between 30 and 90\% [Kohajdová et al., 2012]. They can be classified into three different groups: low-TDF sources (30$-50 \mathrm{~g} / 100 \mathrm{~g}$ ), medium-TDF (50-70 g/100 g) and high-TDF sources (70-90 g/100 g). Grape seeds and skins fall into the medium-TDF sources $(58.80 \mathrm{~g} / 100 \mathrm{~g}, 56.13 \mathrm{~g} / 100 \mathrm{~g})$. These values are similar to those reported for red grape pomace (51.09- $60.00 \mathrm{~g} / 100 \mathrm{~g}$ ) [Deng et al., 2011; Tseng \& Zhao, 2012].

This study showed also that grape seeds were relatively rich in fat $(16.34 \mathrm{~g} / 100 \mathrm{~g})$, which is mainly concentrated in their seeds and contains about $90 \%$ of monounsaturated fatty acids [Sousa et al., 2014].

\section{Rheological properties of wheat dough}

Application of Mixolab apparatus made it possible to describe the mechanical changes due to mixing and heating which simulate the mechanical work as well as the heat conditions that could be expected for the processes of making and baking the products. The advantage of using Mixolab
TABLE 1. Chemical composition of grape skins and seeds and wheat flour.

\begin{tabular}{lcccc}
\hline & $\begin{array}{c}\text { Wheat fine } \\
\text { flour }\end{array}$ & $\begin{array}{c}\text { Grape } \\
\text { skins }\end{array}$ & $\begin{array}{c}\text { Grape } \\
\text { seeds }\end{array}$ \\
\hline Moisture (g/100 g) & $8.79 \pm 0.04$ & $6.83 \pm 0.25$ & $6.82 \pm 0.30$ \\
Ash (g/ 100 g) & $0.55 \pm 0.02$ & $6.78 \pm 0.15$ & $1.59 \pm 0.06$ \\
Protein (g/ 100 g) & $9.44 \pm 0.16$ & $8.41 \pm 0.32$ & $9.67 \pm 0.16$ \\
Fat (g/ $100 \mathrm{~g})$ & $1.02 \pm 0.03$ & $1.04 \pm 0.05$ & $16.34 \pm 0.38$ \\
TDF (g/ 100 g) & $2.11 \pm 0.07$ & $56.13 \pm 1.54$ & $58.80 \pm 2.14$ \\
Pectin (g/ $100 \mathrm{~g})$ & $\mathrm{nd}$ & $3.43 \pm 0.15$ & $\mathrm{nd}$ \\
Carbohydrate (g/100 g) & 78.09 & 20.81 & 6.78 \\
pH & $6.51 \pm 0.03$ & $4.41 \pm 0.00$ & $5.48 \pm 0.01$ \\
Energy value (kJ/kg) & 15380.48 & 14690.04 & 18750.94 \\
\hline
\end{tabular}

nd - not detected, TDF - total dietary fibre

is that the properties of proteins and starch (and associated enzymes) can be measured in a single test [Hadnadev et al., 2013]. Results of determination of the effect of grape skins and grape seeds on the rheological properties of wheat dough are presented in Table 2.

The addition of grape skins at levels of $10 \%$ and $15 \%$ increased the water absorption (WA). A similar effect was also described by other authors after the addition of mango peel powder, apple fiber, lemon and orange preparation to the wheat dough [Ajila et al., 2008; Kohajdová et al., 2011, 2014]. Water absorption increase was caused by the higher number of hydroxyl groups in the structure of dietary fiber, which enabled more water interactions through hydrogen bonding [Kohajdová et al., 2011].

Opposite effect to WA was observed after grape seeds inclusion to wheat dough. From the literature, it is known that grape seeds contain $44 \%$ lignin, which is the insoluble fraction of dietary fiber in water and has a hydrophobic binding capacity. If this fraction predominates, it is known to be involved in decreased water absorption [Mildner-Szkudlarz et al., 2013].

It was also found that increasing the addition of grape seeds to wheat dough increased its stability (ST). Similar effects on ST were observed by Mironeasa et al. [2012] when grape seed flour was added to wheat dough. This is probably caused by the high percentage of lipids in grape seeds, which are able to form lipoprotein complexes between the starch and other hydrophobic gluten components, resulting in the compacting and stabilization of dough [Mironeasa et al., 2012]. On the other hand, increasing the addition of grape skins to the wheat dough caused a reduction in dough ST. It was earlier reported for dietary fiber incorporated dough that the decrease in ST was due to the decrease in wheat gluten content [Kohajdová et al., 2014].

Moreover, it was concluded that the effect of grape skins and grape seeds on C2 values (maximum consistency during protein weakening) decreased with increasing grape skins and increased with the increment of grape seeds addition. The reduction in the maximum consistency of dough might be the result of gluten dilution, which made the dough less 
TABLE 2. Effect of grape skins and seeds on rheological properties of wheat dough.

\begin{tabular}{|c|c|c|c|c|c|c|c|c|c|}
\hline $\begin{array}{l}\text { Addition } \\
\text { level (\%) }\end{array}$ & $\begin{array}{c}\text { Water } \\
\text { absorption } \\
(\%)\end{array}$ & $\begin{array}{l}\text { Stability } \\
(\mathrm{min})\end{array}$ & $\begin{array}{c}\mathrm{C} 2 \\
(\mathrm{Nm})\end{array}$ & $\begin{array}{c}\mathrm{C} 3 \\
(\mathrm{Nm})\end{array}$ & $\begin{array}{c}\mathrm{C} 4 \\
(\mathrm{Nm})\end{array}$ & $\begin{array}{c}\mathrm{C} 5 \\
(\mathrm{Nm})\end{array}$ & $\begin{array}{c}\mathrm{C} 1-\mathrm{C} 2 \\
(\mathrm{Nm})\end{array}$ & $\begin{array}{c}\mathrm{C} 3-\mathrm{C} 2 \\
(\mathrm{Nm})\end{array}$ & $\begin{array}{c}\mathrm{C} 5-\mathrm{C} 4 \\
(\mathrm{Nm})\end{array}$ \\
\hline 0 & $57.70 \pm 0.10^{\mathrm{a}}$ & $9.98 \pm 0.14^{\mathrm{a}}$ & $0.52 \pm 0.02^{\mathrm{a}}$ & $2.09 \pm 0.03^{\mathrm{a}}$ & $1.79 \pm 0.01^{\mathrm{a}}$ & $2.71 \pm 0.03^{\mathrm{a}}$ & $0.55 \pm 0.01^{\mathrm{a}}$ & $1.56 \pm 0.01^{\mathrm{a}}$ & $0.92 \pm 0.14$ \\
\hline \multicolumn{10}{|c|}{ Grape skins } \\
\hline 5 & $58.80 \pm 0.10^{\mathrm{b}}$ & $9.23 \pm 0.20^{\mathrm{a}}$ & $0.42 \pm 0.02^{\mathrm{b}}$ & $2.10 \pm 0.04^{\mathrm{a}}$ & $1.95 \pm 0.02^{\mathrm{b}}$ & $2.78 \pm 0.02^{\mathrm{a}}$ & $0.68 \pm 0.03^{b}$ & $1.68 \pm 0.02^{\mathrm{b}}$ & $0.83 \pm 0.02^{b}$ \\
\hline 10 & $60.00 \pm 0.20^{c}$ & $7.70 \pm 0.12^{\mathrm{b}}$ & $0.25 \pm 0.02^{\mathrm{c}}$ & $2.15 \pm 0.02^{\mathrm{a}}$ & $1.97 \pm 0.01^{\mathrm{c}}$ & $2.77 \pm 0.04^{\mathrm{a}}$ & $0.85 \pm 0.18^{c}$ & $1.90 \pm 0.02^{\mathrm{c}}$ & $0.80 \pm 0.01^{\circ}$ \\
\hline 15 & $64.80 \pm 0.30^{\mathrm{d}}$ & $6.23 \pm 0.11^{\mathrm{c}}$ & $0.24 \pm 0.01^{\mathrm{d}}$ & $2.21 \pm 0.05^{\mathrm{b}}$ & $2.03 \pm 0.03^{\mathrm{d}}$ & $2.60 \pm 0.02^{\mathrm{b}}$ & $0.87 \pm 0.21^{\mathrm{d}}$ & $1.98 \pm 0.03^{\mathrm{d}}$ & $0.56 \pm 0.01$ \\
\hline \multicolumn{10}{|c|}{ Grape seeds } \\
\hline 5 & $55.20 \pm 0.21^{\mathrm{b}}$ & $10.98 \pm 0.15^{b}$ & $0.59 \pm 0.02^{\mathrm{a}}$ & $2.05 \pm 0.03^{\mathrm{a}}$ & $1.74 \pm 0.01^{\mathrm{a}}$ & $2.64 \pm 0.03^{b}$ & $0.48 \pm 0.14^{b}$ & $1.46 \pm 0.02^{\mathrm{b}}$ & $0.90 \pm 0.02^{a}$ \\
\hline 10 & $53.70 \pm 0.14^{\mathrm{c}}$ & $11.20 \pm 0.18^{c}$ & $0.63 \pm 0.02^{\mathrm{b}}$ & $2.00 \pm 0.02^{\mathrm{b}}$ & $1.67 \pm 0.02^{b}$ & $2.54 \pm 0.02^{\mathrm{c}}$ & $0.47 \pm 0.15^{\mathrm{c}}$ & $1.37 \pm 0.01^{\mathrm{c}}$ & $0.87 \pm 0.01^{a}$ \\
\hline 15 & $51.50 \pm 0.18^{d}$ & $11.70 \pm 0.21^{\mathrm{d}}$ & $0.66 \pm 0.01^{\mathrm{c}}$ & $1.98 \pm 0.02^{\mathrm{c}}$ & $1.64 \pm 0.02^{\mathrm{c}}$ & $2.51 \pm 0.01^{\mathrm{d}}$ & $0.42 \pm 0.02^{\mathrm{d}}$ & $1.32 \pm 0.01^{\mathrm{d}}$ & $0.87 \pm 0.02^{a}$ \\
\hline
\end{tabular}

Means with different letters (a-d) in superscripts are significantly different at $\mathrm{p}<0.05, \mathrm{C} 2$ : protein weakening based on the mechanical work and temperature; C3: starch gelatinization; C4: factor indicating the stability of the starch gel formed; C5: starch retrogradation during the cooling stage.

elastic, more extensible and less resistant [Rosell et al., 2010; Mironeasa et al., 2012].

With an increasing level of grape seeds substitution in wheat dough, the difference between the points $\mathrm{C} 1-\mathrm{C} 2$ decreased. This observation was similar to those reported by Mironeasa et al. [2012], and could be explained by the fact that there was no marked weakening of the dough and gluten network caused by elevated mechanical energy input and temperature [Pastukhov \& Dogan, 2014]. On the contrary, an increase in the value of this parameter was recorded with increasing additions of grape skins to wheat dough.

As for dough torque, at its maximum consistency during starch gelatinization $(\mathrm{C} 3$ and the difference between the points $\mathrm{C} 3-\mathrm{C} 2$ ), an increase in these parameters was found with increased grape skins substitution in the dough. This is due to the quick rupture of starch granules leading to lower pasting temperatures and to higher paste consistency. On the other hand, the addition of grape seeds had the opposite effect on the following parameters. The decrease in the $\mathrm{C} 3$ parameter was because of the slight increase in the quantity of free water in the dough, which consequently intensified starch hydrolysis because of the increased activity of amylase in the flour mix [Minoreasa et al., 2012; Pastukhov \& Dogan, 2014].

It was also observed that $\mathrm{C} 4$ (maximum consistency during amylolytic activity) decreased with an increasing substitution level of grape seeds in the dough. This is accounted for by the fact that the amylolytic activity of amylase in flour increased and the dough consistency decreased. The addition of grape skins at levels of 5, 10 and 15\% resulted in C4 of 1.74, 1.67 , and $1.64 \mathrm{Nm}$, respectively.

Furthermore, the difference between the $\mathrm{C} 5$ and $\mathrm{C} 4$ values, which represent starch degradation, decreased. The lower values (C5-C4) obtained for grape skins indicate a higher resistance to degradation [Hadnadev et al., 2013]. The results showed that the rheological properties of dough play an important role in the production of cookies, as they determine the attributes and characteristics that are used to assess their quality.

\section{Physical properties of cookies}

The effects of the grape skin and grape seed preparations substitution at different levels on the physical properties of cookies such as $a_{w}$, volume, volume index, width, thickness and spread ratio, before baking weight, after baking weight, bake loss, hardness, fracturability and overall acceptability are presented in Table 3. It was found that the volume of cookies significantly decreased $(p<0.05)$ with increased levels of fibers (23.94 and 24.03\% volume reduction). Similar results were observed by Walker et al. [2014] for muffins incorporated with red and white grape pomace. This negative effect on volume might be due to the fibers from the grape skins and grape seeds which damage dough structure, and thus decrease $\mathrm{CO}_{2}$ gas retention in the dough matrix [Walker et al., 2014].

Previously it was reported that the addition of dietary fiber from various sources and substitutes had a negative effect on the width, thickness and spread ratio of the products [Turksoy \& Özkaya, 2011]. This study showed that the addition of grape skin and grape seed preparations adversely affected the thickness and width of cookies. This may be also due to the dilution of gluten [Kohajdová et al., 2014]. Addition of grape skins and grape seeds at the level of $15 \%$ caused decrease in the thickness of cookies by about 8.4 and $13.5 \%$ and in their width by about 8.13 and $3.84 \%$, respectively. This observation is in agreement with those reported by Ajila et al. [2008] and Ashoush \& Gadallah [2011] for biscuits incorporated with mango peel powders and by Kohajdová et al. [2011, 2014] for biscuits incorporated with grapefruit fiber and apple fiber.

In general, the addition of grape skin and grape seed preparations affected the spread ratio in different ways. This parameter was significantly reduced $(\mathrm{p}<0.05)$ when higher levels (10-15\%) of grape skins were added. A reduction in cookie spread ratio was also described after the addition of mango peel powder [Ajila, et al., 2008], apple powder [Kohajdová et al., 2014], orange peel [Nassar et al., 2008], pumpkin pomace, and carrot pomace [Turksoy \& Özkaya, 2011]. On the other hand, the spread ratio of cookies incor- 
porated with $15 \%$ of grape seeds increased by about $10.23 \%$ compared to control sample. The same results of an increasing spread ratio were also reported by Aksoylu et al. [2015] and Mildner-Szkudlarz et al. [2013] after incorporating defatted grape seeds and white grape pomace to biscuits. The increase in the spread factor is related to fat content; i.e. with an increasing fat content there is an increase in spread ratio, and thus the increased spread ratio of cookies may be due to the higher fat content $(16.33 \mathrm{~g} / 100 \mathrm{~g})$ in grape seeds [Aksoylu et al., 2015]

Hardness and fracturability are textural properties which attract significant attention in the evaluation of baked goods, because of their close association with human perception of freshness. It is desirable that these parameters are as low as possible [Assis et al., 2009].

Decreased fracturability and hardness of cookies was observed with different levels of grape preparation (grape skins and grape seeds). This may be due to the relatively higher water content in cookies even after their baking [Min et al., 2010]. The increased amount of grape skin and grape seed preparations from 5 to $15 \%$ resulted in a considerable decrease in the amount of force required to break the cookies. On the other hand, no significant differences $(\mathrm{p}>0.05)$ were observed between fracturability of cookies with 5 an $10 \%$ of grape skins and 5\% of grape seeds compared to the control sample.

With increasing levels $(5,10,15 \%)$ of grape skins in cookies, hardness decreased to 1583,1543 and $1427 \mathrm{~g}$, respectively. This may be due to the replacement of wheat flour with the grape skins and grape seeds which reduced the content of gluten in the cookie dough, resulting in a retardation of the formation of gluten matrices, which in turn contributed to the substantial decrease in hardness [Chauhan et al., 2016].

The same observations were also found by Mildner-Szkudlarz et al. [2013] for biscuits enriched with white grape pomace at different levels. The various values of hardness due to the restricted activities of amylases in the dough, might be due to the amount of phenolic compounds [Mildner-Szkudlarz et al., 2013]. The most pronounced result from this study was a decrease in hardness of cookies with a greater replacement of grape seeds. The same observations were also reported by Aksoylu et al. [2015] for biscuits incorporated with defatted grape seeds.

\section{Total dietary fiber in cookies}

The total dietary fiber content of cookies substituted with different levels of grape skins and grape seeds are depicted in Table 4. Cookies incorporated with grape skins and grape seeds had a significantly higher $(\mathrm{p}<0.05)$ total dietary fiber content compared to the control sample. Regulation of the European Parliament of the Council (EC) No 1924/2006 of 20 December on Nutrition and Health Claims Made on Foods states that the claim that a food is a source of fiber may be only made if the product contains at least $3 \mathrm{~g}$ of fiber per $100 \mathrm{~g}$ or at least $1.5 \mathrm{~g}$ of fiber per $100 \mathrm{kcal}$. The claim that a foodstuff has a high fiber content may be given only if the product contains at least $6 \mathrm{~g}$ of fiber per $100 \mathrm{~g}$ or at least $3 \mathrm{~g}$ of fiber per $100 \mathrm{kcal}$ [EC Regulation No 1924/2006].

Cookies incorporated with $5 \%$ of grape skins contained $5.72 \mathrm{~g} / 100 \mathrm{~g}$ of total dietary fiber, which indicates that they 
may be considered as a source of dietary fiber. On the other hand, it was found that cookies incorporated with a higher amount of grape skins and grape seeds can be considered as a foods with a high fiber content.

\section{Color characteristics of cookies}

Color is claimed to be the main physical property of foods and agricultural products, because it has been widely demonstrated to well correlate with other physical, chemical and sensorial properties of product quality. In fact, color plays an important role with regard of external quality in food industries and food engineering research [Mendoza et al., 2006]. Results of color measurements of cookies made with different levels of grape skin and grape seed preparations are given in Table 5. The color of grape by-products is affected by many factors such as the variety and maturity of the fruit, but the most important is the drying process of preparations [Grigelmo-Miguel et al., 1999]. It was found that the lightness $\mathrm{L}^{*}$ of the cookies exhibited a decreasing trend with increasing

TABLE 4. Total dietary fibre (TDF) content in cookies.

\begin{tabular}{cc}
\hline $\begin{array}{c}\text { Addition } \\
\text { level }(\%)\end{array}$ & $\begin{array}{c}\text { TDF } \\
(\mathrm{g} / 100 \mathrm{~g})\end{array}$ \\
\hline $\begin{array}{c}\text { (control) } \\
\text { (c) }\end{array}$ & $2.37 \pm 0.10^{\mathrm{a}}$ \\
\hline 5 & $5.72 \pm 0.27^{\mathrm{b}}$ \\
10 & $6.50 \pm 0.32^{\mathrm{c}}$ \\
15 & $8.64 \pm 0.24^{\mathrm{d}}$ \\
\hline & Grape seeds \\
\hline 5 & $6.60 \pm 0.25^{\mathrm{b}}$ \\
10 & $7.16 \pm 0.18^{\mathrm{c}}$ \\
15 & $9.76 \pm 0.23^{\mathrm{d}}$ \\
\hline
\end{tabular}

Means with different letters (a-d) in superscripts are significantly different at $\mathrm{p}<0.05)$. TDF - total dietary fibre. substitution level of grape skin and grape seed preparations. The reducing values of $\mathrm{L}^{*}$ indicated that the cookies were darker at higher levels of substitution compared to the control sample. This effect was caused by the presence of natural pigments such as anthocyanins which occurring naturally in the grape skins and grape seeds [Aksoylu et al., 2015].

Moreover, it was observed that cookies with 10 and $15 \%$ substitutions of grape skins were significantly darker than the other samples and control. This fact might be attributed to the Maillard reaction products which are formed from amino acids and reducing sugars during baking the cookies [Mildner-Szkudlarz et al., 2013; Walker et al., 2014]. The grape skins preparation contained more sugar, which facilitates browning reactions. Furthermore, it was shown that the higher levels of grape skins in cookies decreased redness for a lower $\mathrm{a}^{*}$ value, thus approaching the green color, and decreased yellowness for a lower $b^{*}$ value. The resulting color of cookies was dark green-blue. Acun \& Gül [2014] reported a decrease in the color values of darkness $\mathrm{L}^{*}$, an increase in redness $\mathrm{a}^{*}$, and decreased yellowness $b^{*}$ in cookies made with the use of flour from grape seeds, which was in agreement with our results. It is known that grape seeds are rich in polyphenolic compounds [Walker et al., 2014].

As the supplemented levels of grape seeds preparation in cookies increased, the $\mathrm{a}^{*}$ value increased compared to the control cookies $(\mathrm{p}<0.05)$. It was previously reported that when the grape seeds are used as a powder and disperse more homogeneously to the dough, the $\mathrm{a}^{*}$ values incraese remarkably [Aksoylu et al., 2015]. It was also observed that the $b^{*}$ values decreased with a higher addition of grape seeds in the cookies. This may be due to the fact that grape seeds contain a high amount of anthocyanin, a red-blue natural pigment [Aksoylu et al., 2015]. The $\Delta \mathrm{E}$ of cookies was also influenced by the grape skins and grape seeds, and $\Delta \mathrm{E}$ values increased with an increasing substitution of grape skin and seed preparations in cookies. The composition of the raw materials significantly affects the color differences, since the processing and baking conditions were the same for all of the mixtures [Batista et al., 2016]. The chroma parameter $\left(C^{*}\right)$ represents the color saturation of the cookies, i.e. indicates the intensity

TABLE 5. Differences in colour parameters of cookies samples.

\begin{tabular}{|c|c|c|c|c|c|c|}
\hline $\begin{array}{l}\text { Addition } \\
\text { level (\%) }\end{array}$ & $\mathrm{L}^{*}$ & $a^{*}$ & $b^{*}$ & $\Delta \mathrm{E}$ & $\mathrm{C}^{*}$ & $\begin{array}{l}\mathrm{H} \\
\left({ }^{\circ}\right)\end{array}$ \\
\hline $\begin{array}{c}0 \\
\text { (control) }\end{array}$ & $70.13 \pm 0.10^{\mathrm{a}}$ & $2.87 \pm 0.13^{\mathrm{a}}$ & $18.79 \pm 0.09^{\mathrm{a}}$ & $0^{\mathrm{a}}$ & $19.00 \pm 0.06^{\mathrm{a}}$ & $81.31 \pm 0.37^{\mathrm{a}}$ \\
\hline \multicolumn{7}{|c|}{ Grape skins } \\
\hline 5 & $53.13 \pm 0.27^{b}$ & $-0.36 \pm 0.25^{b}$ & $4.40 \pm 0.08^{b}$ & $22.52 \pm 0.04^{b}$ & $4.44 \pm 0.07^{\mathrm{b}}$ & $96.64 \pm 0.45^{b}$ \\
\hline 10 & $50.41 \pm 0.82^{\mathrm{c}}$ & $-0.51 \pm 0.01^{\mathrm{c}}$ & $2.60 \pm 0.10^{c}$ & $25.73 \pm 0.67^{c}$ & $2.62 \pm 0.10^{c}$ & $96.27 \pm 0.22^{\mathrm{c}}$ \\
\hline 15 & $41.81 \pm 0.77^{\mathrm{d}}$ & $-1.12 \pm 0.04^{d}$ & $2.22 \pm 0.06^{\mathrm{d}}$ & $33.05 \pm 0.55^{\mathrm{d}}$ & $2.46 \pm 0.08^{\mathrm{d}}$ & $116.74 \pm 0.88^{\mathrm{d}}$ \\
\hline \multicolumn{7}{|c|}{ Grape seeds } \\
\hline 5 & $62.75 \pm 0.28^{b}$ & $4.23 \pm 0.02^{b}$ & $16.05 \pm 0.08^{b}$ & $8.00 \pm 0.35^{b}$ & $16.60 \pm 0.08^{\mathrm{b}}$ & $75.21 \pm 0.15^{\mathrm{b}}$ \\
\hline 10 & $57.37 \pm 0.36^{c}$ & $3.27 \pm 0.02^{\mathrm{c}}$ & $13.05 \pm 0.20^{c}$ & $14.50 \pm 0.40^{c}$ & $13.46 \pm 0.20^{c}$ & $75.91 \pm 0.11^{\mathrm{c}}$ \\
\hline 15 & $54.35 \pm 0.69^{\mathrm{d}}$ & $4.72 \pm 0.03^{\mathrm{d}}$ & $11.56 \pm 0.10^{\mathrm{d}}$ & $17.50 \pm 0.53^{\mathrm{d}}$ & $12.49 \pm 0.10^{\mathrm{d}}$ & $67.72 \pm 0.24^{\mathrm{d}}$ \\
\hline
\end{tabular}

Means with different letters (a-d) in superscripts are significantly different at $\mathrm{p}<0.05$. 


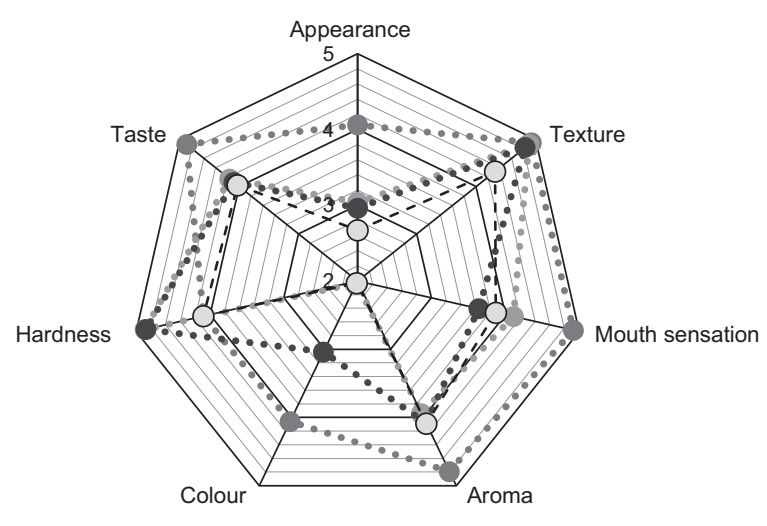

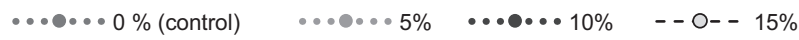

FIGURE 1. Sensory properties of cookies incorporated with grape skins.

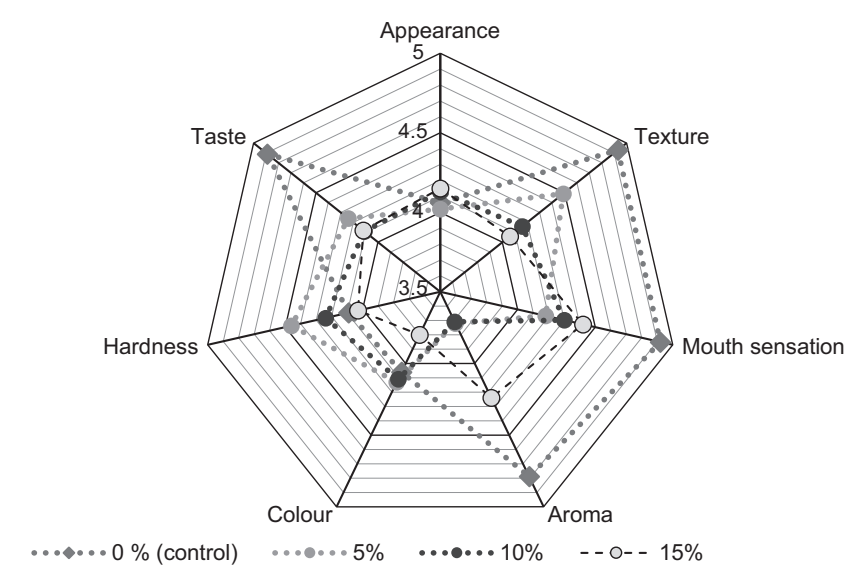

FIGURE 2. Sensory properties of cookies incorporated with grape seeds.

or purity of a color relative to white [Batista et al., 2016]. The cookies with grape skins had a less saturated color. As for hue angle ${ }^{\circ}$, the values ranged from $75.21^{\circ}$ to $67.72^{\circ}$ (grape seeds) and from $96.64^{\circ}$ to $116.74^{\circ}$ (grape skins).

\section{Sensory characteristics of cookies}

The sensory properties of cereal products can be greatly affected by the addition of fiber. Figure 1 and 2 show the effect of the incorporation of grape skins and grape seeds to cookies on their sensory parameters (appearance, texture, sensation in the mouth, aroma, color and taste).

As the addition levels of red grape skins in cookies increased, their color turned green-blue and therefore became less attractive for the panelists. On the other hand, the panelists evaluating the color of cookies with grape seeds $(5-10 \%$ substitution), found no significant differences compared to the control sample $(\mathrm{p}>0.05)$.

As the amount of grape preparation in the cookie dough increases, the assigned values for pleasant sensation in the mouth decrease due to an astringent and bitter taste. Davidov-Pardo et al. [2012] reported that the phenolic compounds of grape seeds contributed to the astringent taste of products. It is caused by the interaction between phenolics and saliva in the mouth. The bitter taste and sensation of as- tringency are elicited in grape seeds primarily by the flavan-3-ols including (+)-catechin, (-)-epicatechin, and especially proanthocyanidins [Hoye \& Ross, 2011]. The bitterness of the phenolic compounds present in the grape preparation reduced the perception of sweetness of the enriched cookies, in the same way that sweetness could mask the bitter flavor of the grape preparation [Davidov-Pardo et al., 2012]. The sensory score for the texture of cookies decreased gradually with increased replacement levels of grape seeds. This may be attributed to the grainy texture of the grape seeds-enriched cookies. This effect may be related to the particle size of the red grape seeds flour, and might be remedied by reducing its particle size before its addition to the cookie dough. It was also shown that the pleasant sensation in the mouth increased gradually with increasing cookies enrichment in grape seeds. It is known that fat contributes to the pleasant sensation in the mouth and additionally positively impacts flavor intensity and perception, and that the grape seeds are a rich source of fat [Żbikowska \& Rutkowska, 2008; Mironeasa et al., 2012].

From the study results, it was also concluded that cookies incorporated with $5 \%$ of grape seeds had a comparable overall acceptability (91.44\%) to the control sample. Grape skins could be incorporated up to a level of 5\% in the cookie dough recipe, without affecting their overall acceptability.

Walker et al. [2014] had reported that the maximum amount of grape skins addition in cereal products are between 5 and $15 \%$ compared to the control samples. This fact demonstrates the variability of grape skins $\mathrm{s}$ as a means of increasing DF in cereal products, without significantly adversely affecting their sensory characteristics.

\section{CONCLUSIONS}

Results of this study demonstrated that:

- grape skins and seeds are rich sources of TDF;

- incorporation of grape skins and seeds modified rheological properties of wheat dough: addition of grape skins concluded in increasing water absorption and reduction of dough stability, an opposite effect to these parameters were observed with the addition of grape seeds;

- analysis of the physical parameters of cookies incorporated with grape skin and seed preparations showed that the volume and thickness of cookies decreased, and hardness decreased with increasing levels of grape skin and seed preparations;

- sensory evaluation indicated that no significant differences were found in the overall acceptability between cookies incorporated with $5 \%$ of grape seeds and the control cookies.

In conclusion, it could be summarized that grape skin and seed preparations can be applied as a suitable alternative to increase TDF content of cookies.

\section{RESEARCH FUNDING}

This work was supported by Slovak grant agency VEGA No. 1/0487/16 and ITMS: 26230120006. 


\section{CONFLICT OF INTEREST}

Authors declare no conflict of interest.

\section{REFERENCES}

1. AACC 1995, Approved Methods of the American Association of Cereal Chemists, (9th ed.). Method 32-05: Total Dietary Fiber in St. Paul, MN, USA.

2. AACC 2000, Approved Methods of the American Association of Cereal Chemists (10th ed.). Methods 08-01,30-25,44-15A, 46-10,54-10,54-21, St. Paul, MN, USA.

3. Acun S., Gül H., Effects of grape pomace and grape seed flours on cookie quality. Qual. Assur Saf. Crop., 2014, 6, 81-88.

4. Ajila C.M., Leelavathi K., Rao U.P., Improvement of dietary fiber content and antioxidant properties in soft dough biscuits with the incorporation of mango peel powder. J. Cereal Sci., 2008, 48, 319-326.

5. Aksoylu Z., Çağindi Ö., Köse E., Effects of blueberry, grape seed powder and poppy seed incorporation on physicochemical and sensory properties of biscuit. J. Food Qual., 2015, 38, 164-174.

6. Alvarez-Jubete L., Auty M., Arendt E.K., Gallagher E., Baking properties and microstructure of pseudocereal flours in gluten-free bread formulations. Eur. Food Res. Technol., 2010, 230, 437-445.

7. AOAC 1995, AOAC Official Methods of Analysis (16th ed). Official Method 985.29: Total Dietary Fiber in Foods-EnzymaticGravimetric Method, AOAC International Arlington, VA, USA.

8. Ashoush I.S., Gadallah M.G.E., Utilization of mango peels and seed kernels powders as sources of phytochemicals in biscuit. World J. Dairy Food Sci., 2011, 6, 35-42.

9. Assis L.M., Zavareze E., Radúnz A., Dias Á., Gutkoski L., Elias M., Propriedades nutricionais, tecnológicas e sensoriais de biscoitos com substituição de farinha de trigo por farinha de aveia ou farinha de arroz parboilizado. Alim. Nutr. Araraquara., 2009, 20, 15-24 (in Portugese; English abstract).

10. Batista R.J.E., de Morais M.P., Caliari M., Júnior M.S.S., Physical, microbiological and sensory quality of gluten-free biscuits prepared from rice flour and potato pulp. J. Food Nutr. Res., 2016, 55,101-107.

11. Chauhan A., Saxena D.C., Singh S., Physical, textural, and sensory characteristics of wheat and amaranth flour blend cookies. Cogent Food Agric., 2016, 2, art. id. 1125773.

12. Davidov-Pardo G., Moreno M., Arozarena I., Marín-Arroyo M.R., Bleibaum R.N., Bruhn C.M., Sensory and consumer perception of the addition of grape seed extracts in cookies. J. Food Sci., 2012, 77, S430-S438.

13. deMenezes E.W., Grande F., Giuntini E.B., Lopes T.D.CV., Dan M.C.T., Prado S.B.R., Franco B.D.G.D., Charrondiére U.R., Lajolo F.M., Impact of dietary fiber energy on the calculation of food total energy value in the Brazilian. Food Composition Database. Food Chem., 2016, 193, 128-133.

14. Deng Q., Penner M.H., Zhao Y., Chemical composition of dietary fiber and polyphenols of five different varieties of wine grape pomace skins. Food Res. Int., 2011, 44, 2712-2720.

15. García-Lomillo J., González-SanJosé M.L., Applications of wine pomace in the food industry: approaches and functions. Compr. Rev. Food Sci. Food Saf., 2017, 16, 3-22.
16. Grigelmo-Miguel N., Martín-Belloso O., Comparison of dietary fibre from by-products of processing fruits and greens and from cereals. LWT - Food Sci. Technol., 1999, 32, 503-508.

17. Hadnađev M., Dapčević Hadnadev T., Šimurina O., Filipčev B., Empirical and fundamental rheological properties of wheat flour dough as affected by different climatic conditions. J. Agric. Sci. Technol., 2013, 15, 1381-1391.

18. Hoye Jr. C., Ross C.F., Total phenolic content, consumer acceptance, and instrumental analysis of bread made with grape seed flour. J. Food Sci., 2011, 76, 428-436.

19. Jambrec D., Pestorić M., Sakač M., Nedeljković N., Hadnađev M., Filipčev B., Šimurina O., Sensory and instrumental properties of novel gluten-free products. J. Process Ener. Agric., 2013, 17, 2, 86-88.

20. Karnopp A.R., Figueroa A.M., Los P.R., Teles J.C., Simões D.R.S., Barana A.C., Granato D., Effects of whole-wheat flour and bordeaux grape pomace (Vitis labrusca L.) on the sensory, physicochemical and functional properties of cookies. Food Sci. Technol., 2015, 35, 750-756.

21. Kohajdová Z., Karovičová J., Jurasová M., Influence of carrot pomace powder on the rheological characteristics of wheat flour dough and on wheat rolls quality. Acta Sci. Pol. Technol. Aliment., 2012, 11, 381-387.

22. Kohajdova Z., Karovicova J., Jurasova M., Kukurova K., Application of citrus dietary fibre preparations in biscuit production J. Food Nutr. Res., 2011, 50, 182-190.

23. Kohajdová Z., Karovičová J., Magala M., Kuchtová V., Effect of apple pomace powder addition on farinographic properties of wheat dough and biscuits quality. Chem. Pap., 2014, 68, 1059-1065.

24. Larrauri J.A., New approaches in the preparation of high dietary fibre powders from fruit by-products. Trends Food Sci. Technol., 1999, 10, 3-8.

25. Levent H.J., Bilgiçli N., Quality evaluation of wheat germ cake prepared with different emulsifiers. J. Food Qual., 2013, 36, 334-341.

26. Maner S., Sharma A. K., Banerjee K., Wheat flour replacement by wine grape pomace powder positively affects physical, functional and sensory properties of cookies. Proc. Natl. Acad. Sci. India Sect. B., 2017, 87, 1, 109-113.

27. Mendoza F., Dejmek P., Aguilera J., Calibrated color measurements of agricultural foods using image analysis. Postharvest Biol. Technol., 2006, 41, 285-295.

28. Mildner-Szkudlarz S., Bajerska J., Zawirska-Wojtasiak R., White grape pomace as a source of dietary fibre and polyphenols and its effect on physical and nutraceutical characteristics of wheat biscuits. J. Sci. Food Agric., 2013, 93, 389-395.

29. Min B., Bae I.Y., Lee H.G., Yoo S.H., Lee S., Utilization of pectin-enriched materials from apple pomace as a fat replacer in a model food system. Bioresour. Technol., 2010, 101, 5414-5418.

30. Mironeasa S., Codina G.G., Mironeasa C., The effect of wheat flour substitution with grape seed flour on the rheological parameters of the dough assessed by Mixolab. J. Texture Stud. 2012, 43, 40-48.

31. Nassar A.G., Abdel-Hamied A.A., El-Naggar E.A., Effect of citrus by-products flour incorporation on chemical, rheological and organolepic characteristics of biscuits. World J. Agric. Sci., 2008, 4, 5, 612-616. 
32. Parliament, E. Regulation (EC) No 1924/2006 of the European Parliament and of the Council of 20 December 2006 on nutrition and health claims made on foods. E. Parliament (Ed.), 2006, 1924/2006.

33. Pastukhov A., Dogan H., Studying of mixing speed and temperature impacts on rheological properties of wheat flour dough using Mixolab. Agron Res., 2014, 12, 3, 779-786.

34. Popov-Raljič J., Mastilovič J., Petronijevič J., Kevrešan Ž., Demin M., Sensory and color properties of dietary cookies with different fiber sources during 180 days of storage. Hem. Ind., 2013, 67, 123-134.

35. Rosell C.M., Santos E., Collar C., Physical characterization of fiber-enriched bread doughs by dual mixing and temperature constraint using the Mixolab®. Eur. Food Res. Technol., 2010, 231, 535-544.

36. Sousa E.C., Uchôa-Thomaz A.M.A., Carioca J.O.B., Morais S.M.D., Lima A.D., Martins C.G., Chemical composition and bioactive compounds of grape pomace (Vitis vinifera L.), Benitaka variety, grown in the semiarid region of Northeast Brazil. Food Sci. Technol. Campinas, 2014, 34, 135-142.

37. Tseng A., Zhao Y., Effect of different drying methods and storage time on the retention of bioactive compounds and antibacterial activity of wine grape pomace (Pinot Noir and Merlot). J. Food Sci., 2012, 77, H192-H201.

38. Turksoy S., Özkaya B., Pumpkin and carrot pomace powders as a source of dietary fiber and their effects on the mixing properties of wheat flour dough and cookie quality. Food Sci. Technol. Res., 2011, 17, 545-553.

39. Walker R., Tseng A., Cavender G., Ross A., Zhao Y., Physicochemical, nutritional, and sensory qualities of wine grape pomace fortified baked goods. J. Food Sci., 2014, 79, S1811—S1822.

40. Yu J., Ahmedna M., Functional components of grape pomace: their composition, biological properties and potential applications. Int J. Food Sci. Technol., 2013, 48, 221-237.

41. Żbikowska A., Rutkowska J., Possibility of partial replacement of fat by inuline in cookies in order to decrease their caloric value. Pol. J. Food Nutr. Sci., 2008, 58, 113-117.

42. Zielińska M., Zapotoczny P., Markowski, M., Colour standard and homogenous groups of dried carrots of 34 commercial varieties. Pol. J. Food Nutr. Sci., 2005, 14, 51-56.

Submitted: 14 February 2017. Revised: 16 June 2017, 21 July 2017, 28 February 2018. Accepted: 7 March 2018. Published on-line: 9 May 2018. 